\title{
3D-Printed Nose-to-Larynx Airway Model, Preliminary Study
}

\author{
Anna Park and Young Sam Yoo \\ Department of Otorhinolaryngology-Head and Neck Surgery, Sanggye Paik Hospital, College of Medicine, Inje University, Seoul, Korea
}

\section{$3 \mathrm{D}$ 프린터로 제작한 비강-인후두 기도 모델-예비연구}

박 안 나·유 영 삼

인제대학교 의과대학 상계백병원 이비인후과학교실

\author{
Received February 1, 2017 \\ Revised March 6, 2017 \\ Accepted March 10, 2017 \\ Address for correspondence \\ Young Sam Yoo, MD, PhD \\ Department of Otorhinolaryngology- \\ Head and Neck Surgery, \\ Sanggye Paik Hospital, \\ College of Medicine, Inje University, \\ 1342 Dongil-ro, Nowon-gu, \\ Seoul 01757, Korea \\ Tel $+82-2-950-1104$ \\ Fax +82-2-935-6220 \\ E-mail entyoo@empal.com
}

Background and Objectives Flexible fiberscopy is essential in the examination of the nose to larynx airway. However, the instrument is sensitive to manipulation and can sometimes be damaged when excessive external force is applied. In addition, patients can be injured during fiberscopic examination. In this regard, a airway model mimicking the human airway passage was developed for the education of fiberscopy to minimize the danger to both patient and fiberscope.

Materials and Method Neck CT data was used to 3D-print the airway model. Using the 3D doctor software, the outlines of the air-filled cavities were extracted. The outline data was modified to make the inside of the outline empty and the outside filled with 3D ink resin. The airway data was used to 3D-print the replica in three pieces, which were then assembled into one. Flexible laryngoscopic examination of nose to larynx was performed using the nose-tolarynx airway model, and for a male patient enrolled in the study. Virtual endoscopy was performed using the same CT data. The examination data were then compared frame by frame with regards to the shapes and positions of nasal inlet, inferior turbinate, torus tubarius, hypopharynx, epiglottis and vocal cord.

Results The airway model was very similar in shape and position of the anatomic landmarks compared with real human airway examined by the fiberscope.

Conclusion The results of 3D-printed airway model showed similar shapes as the real human airway, and real time endoscopy could be done using the model. This technique can be extended to make models of tubed organs such as the intestine or the bronchial tree.

Korean J Otorhinolaryngol-Head Neck Surg 2017;60(6):301-7

Key Words Airway model Fiberscope $\cdot 3 \mathrm{D}$ printer.

\section{서 론}

의학교육은 인체를 대상으로 하므로 그 과정에서 인체 혹 은 시신을 이용하는 경우가 많다. 교육 내용에 따라서는 인체 를 모방하여 만든 모델을 활용하기도 한다. ${ }^{1-3)}$

시신을 이용하는 경우 실제 인체를 이용한다는 장점이 있지

This is an Open Access article distributed under the terms of the Creative Commons Attribution Non-Commercial License (http://creativecommons.org/licenses/by-nc/4.0) which permits unrestricted non-commercial use, distribution, and reproduction in any medium, provided the original work is properly cited.
만 항시 사용할 수는 없다. 모델을 이용하는 경우 항상 활용이 가능하지만 실제 인체와 구조는 유사해 보여도 성질이 다르다.

특히 이비인후과 영역에서 코, 인두, 후두 등을 검사 시 경성 혹은 굴곡형내시경을 많이 사용하는데, 실제로 인체에 사용 하면서 직접 그 사용법을 익히는 것이 보통이다.

따라서 비강, 인두, 후두 모델을 이용하여 미리 해부학적인 공부를 하고 내시경으로 연습 후 익숙하게 사용을 할 수 있게 되면 인체에 적용하는 것이 더 안전하고 효율적이다. 또한 경 
성 혹은 굴곡형내시경은 고가장비이므로 이를 고장 없이 안 전하게 사용하는 데도 도움이 된다. 최근 $3 \mathrm{D}$ 프린팅 기술이 발달하여 이를 활용하면 유용한 모델을 만들 수 있으리라 생각하는데, 현재까지 측두골이나 하악골, 상악골, 두개골을 $3 \mathrm{D}$ 프린터로 만들어 사용하는 예는 많지만 ${ }^{4,5)}$ 비강이나 인두 후두를 만들어 이학적 검사를 하는 도구로 사용한 보고는 없다. 더구나 앞의 연구들은 골 부위를 $3 \mathrm{D}$ 프린터로 제작하 여 수술 전에 절골술 연습을 하거나 수술 후 발생하는 결손 부위를 미리 예측하거나 재건하는 보조수단으로 많이 활용 되고 있다. ${ }^{6)}$ 최근 들어 비강 출혈을 막는 연습용 모델이나 측 두골 해부실습용으로 활용할 수 있는 정교한 모델로 제작되 어지고 있다. ${ }^{7)}$ 유연성이 있는 모델의 예로는 심장 수술을 앞 두고 심장의 영상의학적 자료를 $3 \mathrm{D}$ 프린터로 실리콘 재질의 심장 모델을 인쇄하여 수술 전에 충분히 연습을 하고 수술 하여 성공한 보고도 있고, ${ }^{8)}$ 기관재건을 위한 원통관 형태의 scaffold를 3D 프린터로 인쇄하여 실험을 한 경우도 있다. ${ }^{9)}$

저자는 예비연구로 성인 남자의 경부 전산화단층촬영 자료 를 활용하여 비강에서 시작하여 인두-후두에 이르는 기도의 내공(airway lumen)을 보여줄 수 있는 기도 모델(airway model, 이후 모델)을 만들고 이를 이용하여 굴곡형내시경의 사용법 을 교육하는 모델로 활용할 수 있는지 알아보고자 하였다.

\section{재료 및 방법}

비강-인두-후두 내공을 재구성한 모델을 제작하기 위하여 이비인후과적으로 문제가 없고 과거에 이비인후과에서 수술 을 받은 병력이 없는 48 세 성인 남자 1 인의 경부 전산화단층 촬영(neck CT) 데이터를 사용하였다. 실험 대상에서 촬영한 axial CT와 coronal CT의 모든 frame은 Digital Imaging and Communications in Medicine 형식으로 저장하여 사용하였 다. CT 기종은 Toshiba Aquillion(Toshiba, Tokyo, Japan)으 로 촬영은 Neck-helical-CE-3-phase로 $120 \mathrm{kVp}$, Exp 100, $\mathrm{ST}=2, \mathrm{Z}=1, \mathrm{~L}=50, \mathrm{~W}=300$ 의 조건을 기본으로 하였다. Axial $\mathrm{CT}$ 는 정수리에서 흥골(sternum) 상부(쇄골부위)까지 촬영하 였고 $2 \mathrm{~mm}$ 간격의 자료를 받았다. Coronal CT는 비첨에서 후두부까지의 자료를 $3 \mathrm{~mm}$ 간격으로 받았다.
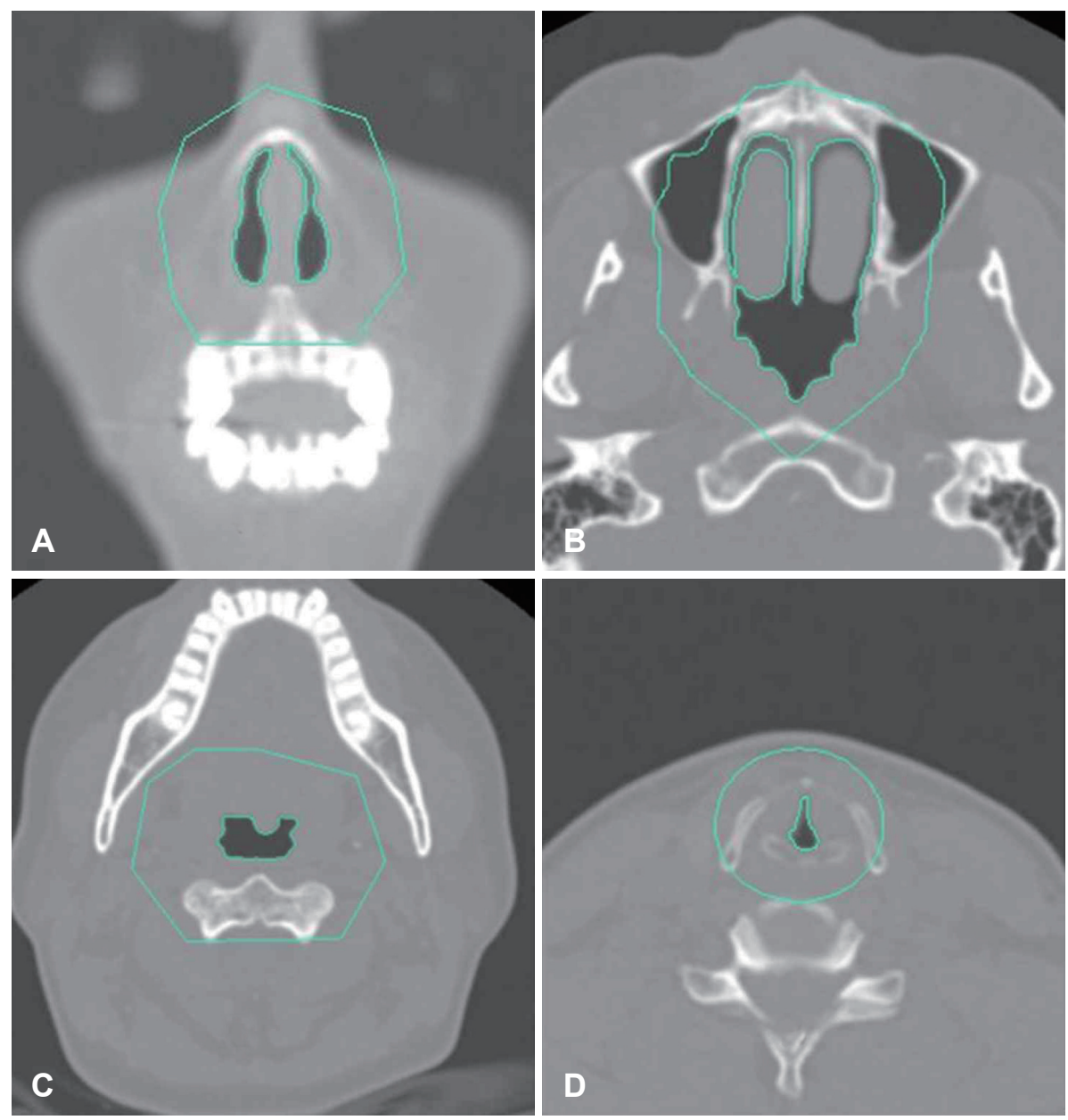

Fig. 1. Boundaries drawn from each image. Coronal view showing nasal inlet (A). Axial view showing nasopharynx (B). Axial view showing pharynx (C). Axial view showing vocal cord (D). 
영상분석 및 삼차원 재건 소프트웨어는 3-D doctor 4.0 (Ablesoftware, Lexington, MA, USA)을 사용하였고, 결과 로 나오는 영상은 캡쳐 후 저장하였다. 자료의 처리 및 실제 모델 제작은 올메이드코리아(Paju, Korea)에서 시행하였고, 가 상내시경(virtual endoscopy)은 Xelis 3D(Infinitt Healthcare, Seoul, Korea)를 사용하여 영상을 만들었고 굴곡형내시경은 VNL-1170STK(Pentax, Montvale, NJ, USA)를 사용하였다.

\section{기도 내면의 외곽선(Boundary) 자료 제작 및 실제 모델 제작}

기도는 점막과 공기가 접하는 부위이므로 CT 음영의 차이 가 육안상으로도 명확하다. 3D-doctor에서 역치를 적절히 조절하여 육안으로 구별이 잘 되는 역치에서 기도 내면의 외 곽선(boundary)을 그리도록 설정하였고, 동일 작업을 비공 골에서 흥골(sternum) 상부까지의 모든 영상 frame에서 하였 다(Fig. 1).

이때 기도 내면을 재구성한 폐곡선의 최소 직경이 $5 \mathrm{~mm}$ 이상이 되도록 조정하였다.

기도 내경을 재구성한 자료를 바탕으로 기도 내경에서 외 측으로 5 20 mm 정도 떨어져서 기도 내경을 재구성한 모양 과 유사한 별도의 폐곡선을 수작업으로 추가하여 그렸다. 이 는 저자가 맞춤형 몽고메리 $\mathrm{T}$ 튜브를 제작한 방법과 유사한 방법을 사용하였다. ${ }^{10)}$ 작업의 편의를 위하여 전비강에서 비 인강 직전까지는 coronal CT를 사용하였고, 비인강에서 후두 까지는 axial CT를 사용하였다. 작업은 비강, 비인강, 인두후 두의 3부분으로 나누어 각각의 파일로 저장하였다(Fig. 1).

기도 내경의 외곽선을 모은 입체 영상으로 석고 모델을 제 작하고자 설계 프로그램인 computer-aided design(CAD)의 호환 형식 중 하나인 stereo lithography(file format native to the stereolithography CAD software created by 3D systems) 파일로 저장하였다. 이를 바탕으로 ZPrinter450(Contex, Rockville, $\mathrm{MD}, \mathrm{USA}$ )을 이용하여 모델을 제작하였다. 모델 제작 재 료는 high performance composite(ZP150 고성능 복합 파우 더)를 사용하였다.

3 개의 분리된 모델을 해부학적인 위치에 맞게 입체적으로 배열을 하기 위하여 인체 두경부 실리콘 모델을 구입하여 적 절히 삽입 및 고정하여 비공에서 후두까지 연결이 되도록 하 였다(Figs. 2 and 3).

\section{모델을 사용한 굴곡형내시경 사용 가능성 확인}

모델의 비강을 통하여 굴곡형내시경을 좌측 비강으로 삽입 하여 실제 후두내시경을 시행하였고, 이를 녹화한 영상을 분 석하여 해부학적인 구조물의 확인 가능 여부를 점검하였다 (Fig. 4). 또한 인체에서도 좌측 비인강-후두내시경을 시행하 고, 동영상으로 녹화하여 비교 자료로 삼았으며(Fig. 5), 성인 남자의 전산화단층촬영 자료를 이용하여 가상내시경(virtual endoscopy)을 시행하고 녹화하여 중요 구조물 확인의 대조 영상으로 삼았다(Fig. 6). 앞서 만든 영상을 이용하여 모델을 이용한 굴곡형내시경 검사를 시행한 영상에서 비공, 하비갑 개, 비인강의 이관융기(torus tubarius) 인두의 입구, 후두개, 진 성대를 확인할 수 있는지 점검하였고, 모델의 영상이 인체와 가상내시경에서 검사한 영상과 모양, 위치가 유사한지 확인 하였다.

\section{결 과}

본 연구에서는, 1) 3D 프린터를 이용하여 비강에서 진성대 까지 보여줄 수 있는 모델을 제작할 수 있었으며(Fig. 2), 2)
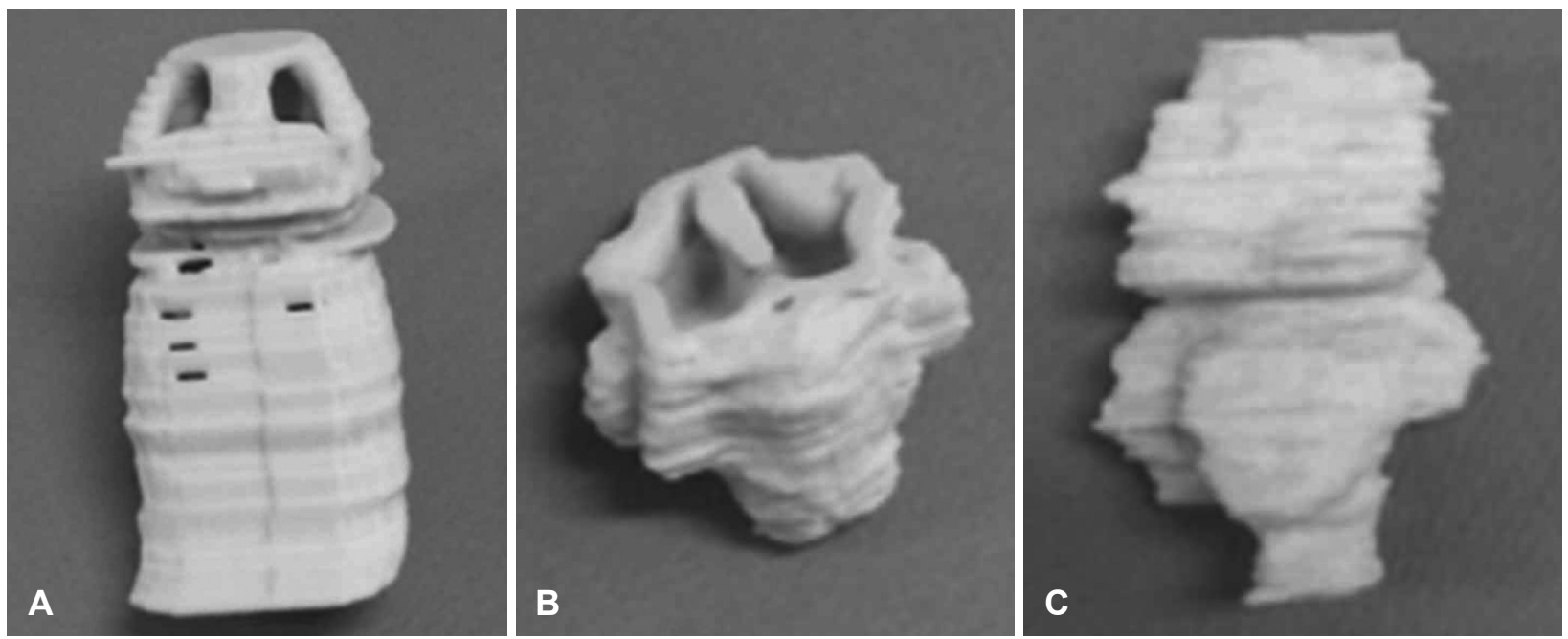

Fig. 2. Nose-to larynx models made by 3D printer. Nose model (A). Nasopharynx model (B). Laryngopharynx model (C). 
굴곡형내시경을 모델의 비강을 통해서 삽입 후 비공, 비강, 비인두, 인두, 후두까지의 중요 구조물들을 모니터 화면으로 관찰할 수 있었고, 3) 실제 인체에서 굴곡형내시경으로 관찰

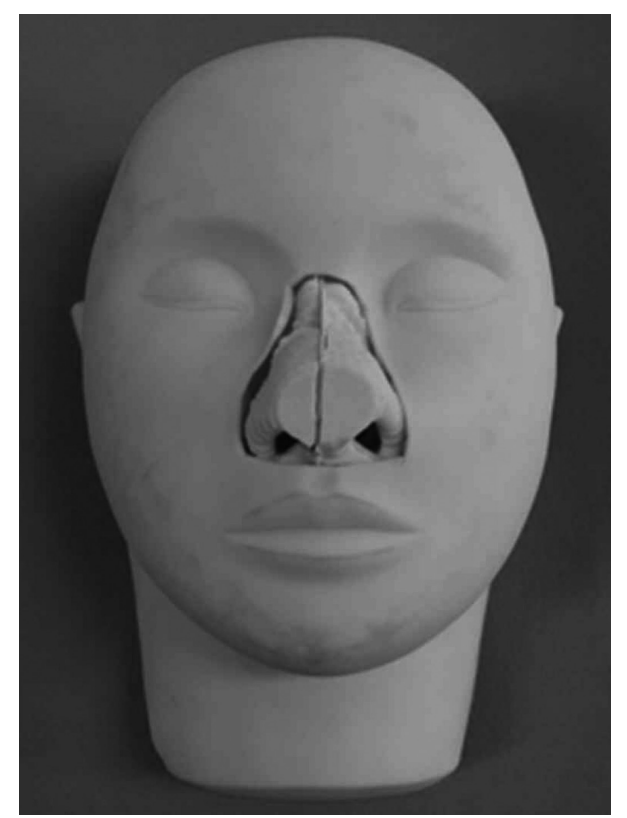

Fig. 3. Airway model assembled in the silicon human head.
한 영상과 모델을 관찰한 영상을 비교한 결과 비공, 비인강, 인두, 후두의 중요 구조물들의 모양이나 위치가 유사하였다 (Figs. 4, 5, and 6).

\section{고 찰}

$3 \mathrm{D}$ 프린터는 최근 의학분야에 많이 활용되고 있다. ${ }^{11-16)}$ 이 를 뒷받침하는 삼차원 재구성 기술(3D reconstruction)은 여 러 분야에 활용되고 있고, 심지어는 화성탐사계획에서도 현 지에 구조물을 제작하는 기술로도 개발 중이다. 저자가 활용 한삼차원 재구성 방법은 인체의 전산화단층촬영 $(\mathrm{CT})$ 자료 를 이용하여 surface rendering 기술을 적용한 후 해부학적인 구조물을 입체적으로 재구성하여 화면상으로 보여주는 기술 이다. ${ }^{15-17)}$ 이를 응용하면 인체의 표면과 내부 장기의 모습을 사 실적으로 보여줄 수 있다. 또한 가상내시경(virtual endoscopy) 을 이용하여 식도나 기도 심지어는 혈관의 내부를 내시경으로 관찰하듯이 화면상으로 보여줄 수도 있다. ${ }^{18-21)}$

삼차원 재구성 기술로 만들어진 입체 영상을 손으로 만질 수 있는 실물로 만들어 주는 것이 3D 프린터이다. 일반 프린 터와 다른 것은 인쇄하는 재료를 다양하게 사용할 수 있어서
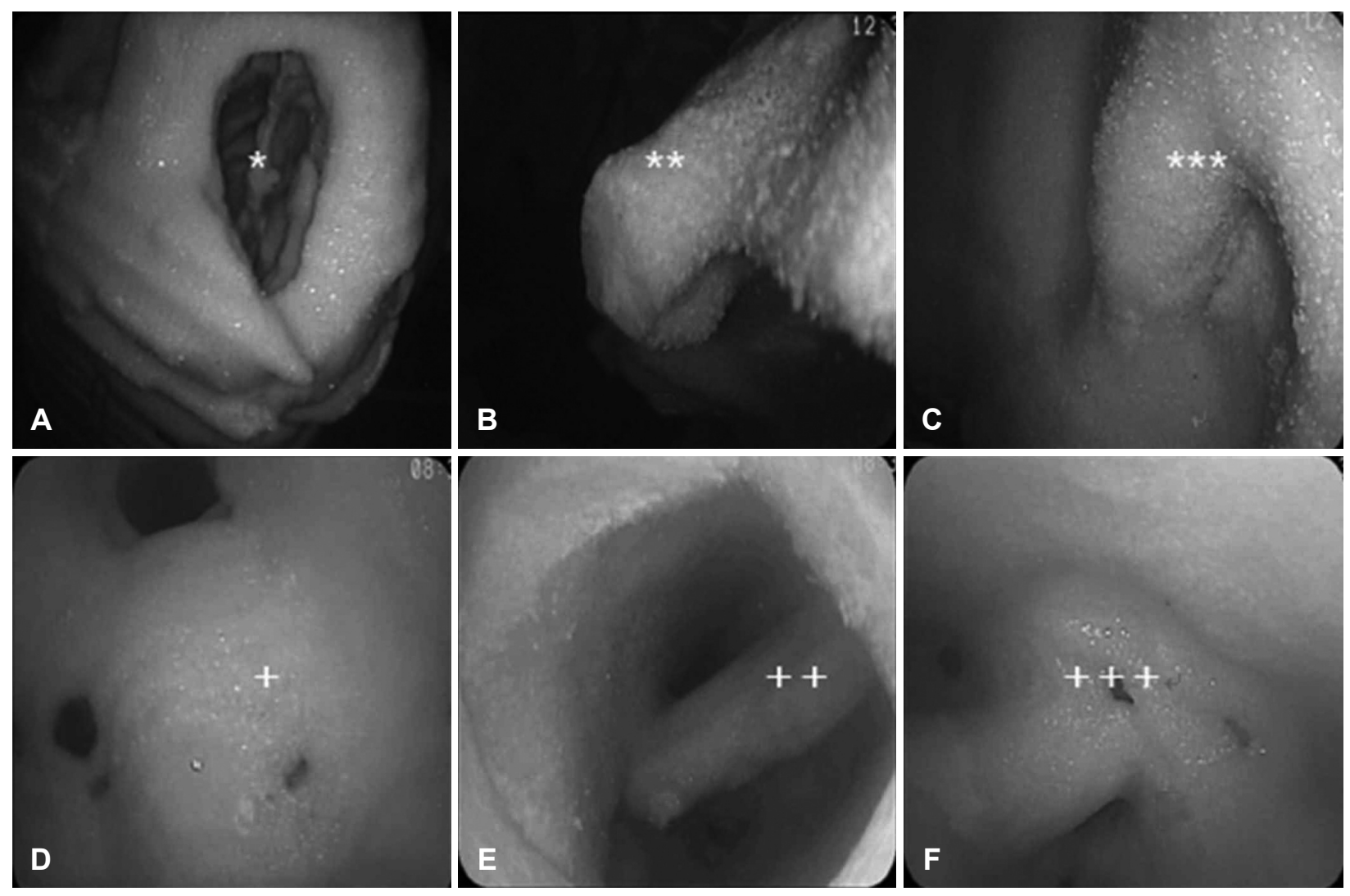

Fig. 4. Images examining model using fiberoptic laryngoscope. Nasal inlet (A). Inferior turbinate (B). Nasopharynx (C). Pharynx (D). Hypopharynx (E). Vocal cord (F). *: nasal inlet, **: inferior turbinate, ***: torus tubarius, +: hypopharyngeal inlet, ++: epiglottis, +++: arytenoid. 


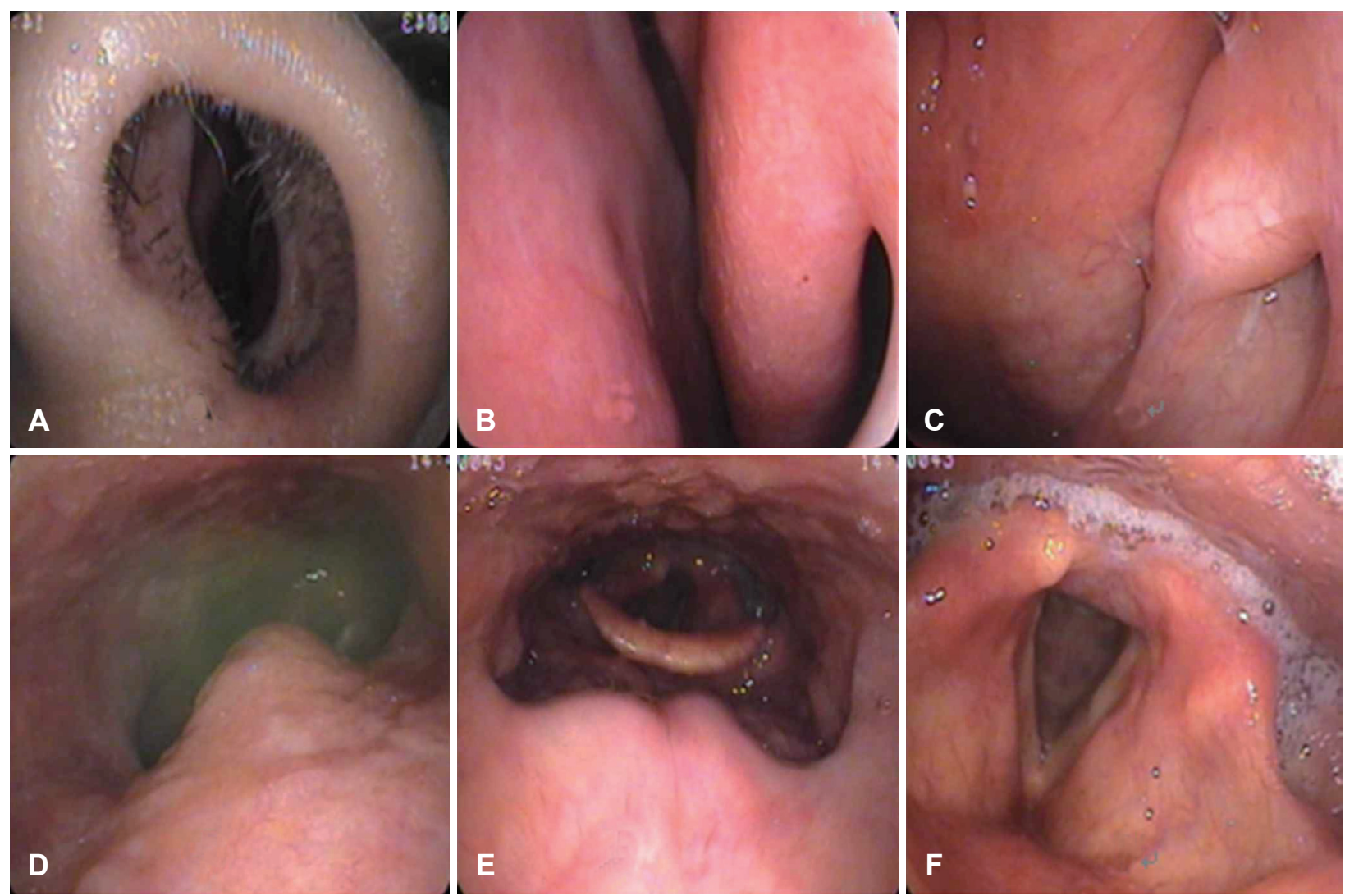

Fig. 5. Images examining human fiberoptic laryngoscope. Nasal inlet (A). Inferior turbinate (B). Nasopharynx (C). Pharynx (D). Hypopharynx $(E)$. Vocal cord $(F)$.

플라스틱, 금속, 초콜릿 등 액체화할 수 있는 재료는 모두 사 용이 가능하다. 프린터의 형태도 기존의 잉크젯 방식으로 노 즐에서 재료를 분사하는 방법이 흔하지만 액상의 재료에 레 이저나 빛을 쪼여 화학적인 변화를 일으켜서 인쇄를 하는 방 법도 있다. ${ }^{8)} 3 \mathrm{D}$ 프린터를 의학적으로 활용한 예는 다음과 같 다. 상악골이나 하악골 교정수술을 하는 경우 골 모형을 제 작하여 시술을 위한 준비를 하고, 이비인후과적으로는 구강 암수술 시 골을 절골 혹은 절제하는 경우 결손부위를 예측하 여 이를 복원시키는 시술을 준비하거나 측두골 모델 제작에 유용하다. ${ }^{5,6,22)}$ 또한 비출혈 지혈 연습 모델, 맞춤형 몽고메리 T-tube 제작 등 다양하게 응용되고 있다. ${ }^{710)}$

앞서 언급한대로 귀, 코, 목의 각 부위는 모두 외부로 개방 되어 있어서 기구를 이용하여 관찰이 가능하다. 최근에는 귀 를 포함한 모든 부위에 대한 이학적 검사와 수술 및 시술이 내시경으로 관찰하면서 가능해졌다. 심지어는 내시경하에 갑 상선 제거 수술이나 경부 임파절 절제 수술, 후두적출 수술 이 가능해져서 내시경 사용은 필수가 되었고, 내시경을 능숙 하게 다루는 것이 수련 중 가장 필요한 항목이 되었다. ${ }^{23-25)}$ 내 시경을 인체에 삽입하는 경우 굴곡형내시경이라 하더라도 표 면이 단단하고 유연성이 없는 반면 기도를 이루는 인체의 내
부는 점막이나 피부로 덮여 있고, 속은 연부조직이나 연골 혹은 뼈로 구성이 되어 있다. 즉, 내시경을 인체에 삽입하여 검사나 시술을 하는 경우 접촉하는 인체가 조금이라도 손상 을 받을 수 있다. 의학적으로 인체에 어떠한 행위를 하더라도 인체에 해가 되지 않도록 해야 하고 해가 발생하는 경우는 최소한으로 해야 하며, 다른 방법을 강구할 수 있으면 다른 방법을 찾는 것이 원칙이다. 의료용 장비 중 굴곡형내시경은 비침습적인 장비로 간주되고 있지만 이는 사용법을 충분히 아는 숙련된 의사가 사용하는 경우이다. 초심자가 교육 없이 사용하면 환자에게 해를 줄 수 있으므로 인체 모델이나 시신 을 이용한 내시경 사용 연습을 충분히 하고, 익숙해지면 전 문의의 감독하에 인체를 통한 검사 및 시술을 하다가 익숙해 지면 혼자 내시경을 사용하게 하는 것이 바람직하다.

모든 의료 행위는 많이 할수록 술기가 늘지만 전공의 수련 시간은 줄고 배워야 할 분야가 늘어나는 현실이라 별도의 교 육이나 실습 없이 각종 술기를 익히는 데 어려움이 있다. 이에 저자들은 이비인후과 수련 시 가장 중요한 이학적 검사를 교 육시킬 도구의 개발을 해야 한다는 생각에 이르렀고, 내시경 사용법을 교육시킬 모델을 찾았지만 오래전부터 사용하던 커다란 머리와 코, 인두, 후두 모델 외에는 적절한 도구를 찾 

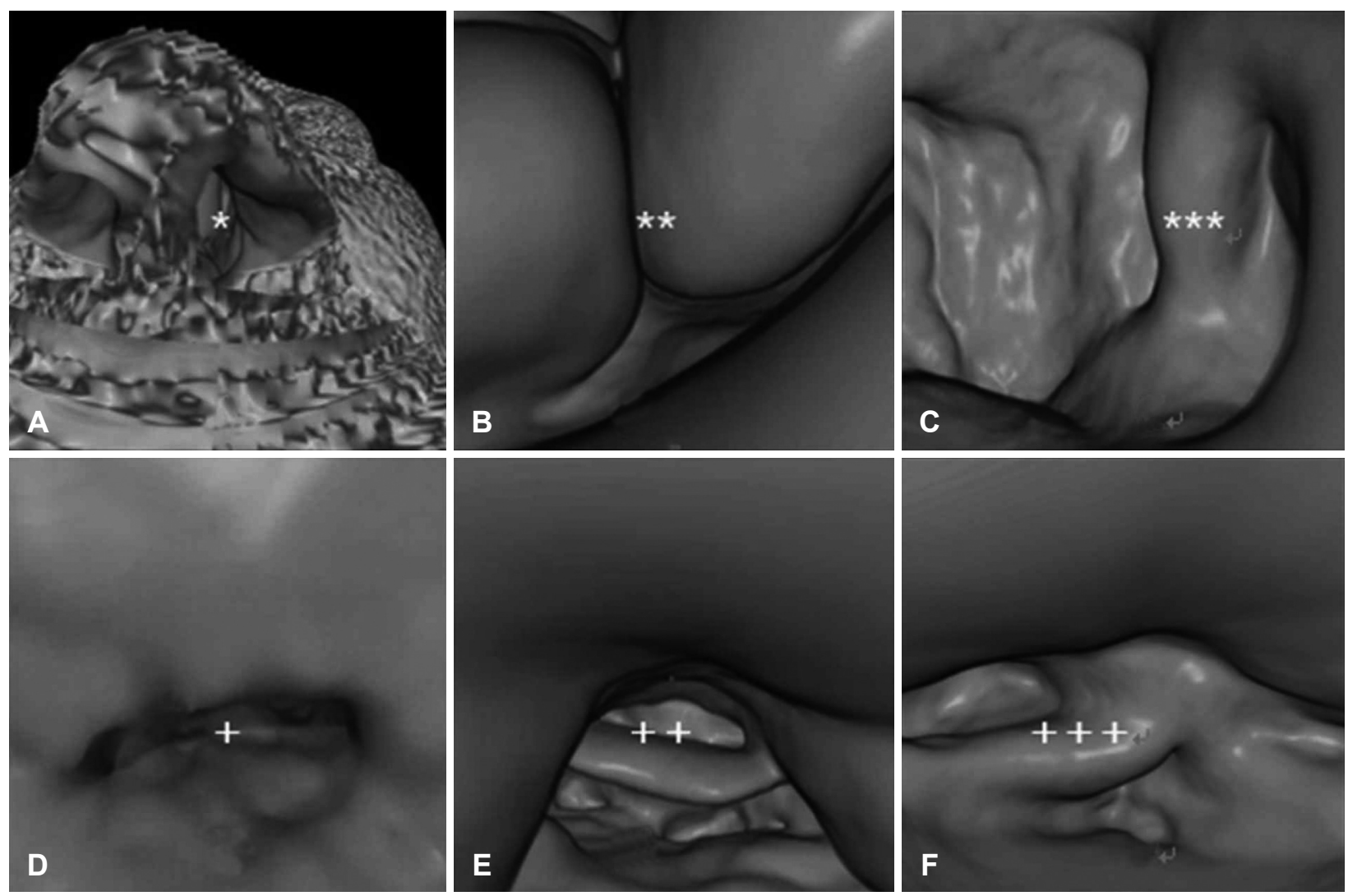

Fig. 6. Images from virtual endoscopy. Nasal inlet (A). Inferior turbinate (B). Nasopharynx (C). Pharynx (D). Hypopharynx (E). Vocal cord $(\mathrm{F})$. *: nasal inlet, $* *$ : inferior turbinate, $* * *$ : torus tubarius, +: hypopharyngeal inlet, ++: epiglottis, +++: arytenoid.

을 수 없었다. 또한 기존에 발표된 3D 프린터로 제작한 모델 들은 비강에서 후두에 이르는 기도를 구현한 것들이 없어서 교육용 재료를 직접 제작해야겠다는 판단을 내렸다. 기존 모 델들은 대부분 골 부위를 재구성하여 절골술이나 비출혈 지 혈 방법 교육 혹은 상악이나 하악을 절골 혹은 절제하는 수 술 시 미리 결손부위를 예측하여 가상수술을 하는 도구로 사 용하는 정도였다. ${ }^{67,22)}$ 즉 내시경을 삽입하여 내공(lumen) 내 의 구조물을 관찰할 수 있는 모델은 없었다. 이에 저자들은 맞춤형 몽고메리 $\mathrm{T}-$ 튜브를 제작했던 경험을 바탕으로 비공 (nostril)에서부터 인두(pharynx)와 후두(larynx)까지 이어지는 피부나 점막으로 구성된 기도의 내공(airway lumen)의 모습을 사실대로 구현할 방법으로 경부 전산화단층촬영 자료를 이 용하고, 삼차원 재구성 기법을 응용하여 기도의 내공의 모습 을 구현하였고 이를 $3 \mathrm{D}$ 프린터로 인쇄하여 기도 모델을 제작 하였다. 이를 대상으로 굴곡형내시경 검사를 하여 비강에서 후두에 이르는 중요한 해부학적 구조물을 확인할 수 있었다.

모델을 관찰한 영상 자료를 인체의 굴곡형내시경 검사 영 상, 가상내시경 영상과 비교한 결과 주요 해부학적 구조물의 모양과 위치가 유사하여 이학적 검사 모델로 사용할 수 있다 고 판단되었다.
본 연구에서 모델의 제작과정의 제한점에 대해 언급한다 면, 1) 모델을 한 조각으로 만들지 않고 3조각으로 만든 점, 2) Axial CT만 사용하지 않고 coronal CT를 같이 사용한 점, 3) 기도의 내경이나 외부를 수기로 그리고 최소 직경이 $5 \mathrm{~mm}$ 를 넘게 그린 점, 4) 단단한 석고재료를 사용하고, 얼굴전체 의 형태로 만들지 않은 점 등을 들 수 있다.

모델을 여러 조각으로 나누어 제작한 이유는 비강에서는 내공(lumen)의 방향이 수평을 이루다가 비인강을 지나면 수 직으로 내려가서 내공의 윤곽선을 그대로 따라 그리는 데 어 려움이 있어서 비강, 비인강, 후두 등으로 나누어 제작하였다. 향후 능숙해지면 한 덩어리로 모델을 제작할 수 있으리라 생 각한다.

똑같은 이유로 비강에서는 coronal CT를 이용하여 내공의 윤곽선을 그렸고 비인강부터는 axial CT를 이용하여 윤곽선 을 그렸으며, 3조각으로 만든 모델은 실리콘으로 제작된 두 부 모형을 파서 고정시켰다. 또한 내공을 이루는 폐곡선의 최 소 직경이 $5 \mathrm{~mm}$ 를 넘도록 손으로 그린 이유는 자동으로 윤 곽선을 그리는 경우 최소 직경이 $5 \mathrm{~mm}$ 이하로 나와 굴곡형 내시경을 삽입할 수 없게 되어서이다.

본 모델은 내시경으로 관찰하는 연습용으로 중요한 구조 
물을 관찰하고 부드럽게 후두까지 삽입하여 관찰하는 연습 을 위한 모델이라 기도 내공의 윤곽선의 크기를 임의로 조절 하였다.

모델을 제작한 재료를 석고로 사용하고 기도의 내면을 받 쳐주는 외부의 모습이 얼굴 모양으로 나오도록 하지 않고 임 의 모양으로 수기로 그려서 프린트한 이유는 인쇄재료 사용 량 절감이 목적이었다. $3 \mathrm{D}$ 프린터의 인쇄재료는 아직은 고가 이고 기도 내공(airway lumen)은 내면만을 보여 주면 되며, 그 외부는 모양은 상관없이 기도를 지지만 해주면 된다. 또한 $\mathrm{T}$-튜브 제작 시, 실리콘 재질로 인쇄를 할 수 있었지만 비강 에서 후두에 이르는 모델은 시험적으로 실리콘 재질로 출력 을 해보니 모델이 찢어지는 기술상의 문제 발생으로 기술적 보완이 필요하여 석고 모델 제작을 먼저 하여 모델의 활용 가 능성을 우선 검토해 보고자 하였다.

향후 연구는 석고 모델은 더 세밀하게 만들어 보고 재료를 실리콘이나 고무 종류로 재료를 변경하여 탄력성이 있는 기 도 모델을 만들어서 굴곡형내시경 삽입 시 인체에 더 가까운 경험을 할 수 있도록 하는 것이다.

전산화단층 자료는 절단 단면 두께(slice thickness)를 2 $\mathrm{mm}$ 에서 $1 \mathrm{~mm}$ 나 더 작은 두께의 자료로 사용하면 더 정교한 모델 제작이 가능하리라 생각한다.

본 연구에서 $3 \mathrm{D}$ 프린터로 기도 모델 제작이 가능하였고 굴곡형내시경 검사 결과 각 구조물의 모양과 위치가 실제 인 체와 유사하였다.

이 방법을 활용하면 귀의 이학적 검사 모델, 비내시경 수술 모델, 식도위내시경 모델도 제작이 가능할 것이다. 본 연구에 서 만든 모델을 바탕으로 교육용 모델을 제작한다면 3D 프 린터로 주형을 만든 후 대량생산도 가능하리라 본다.

\section{REFERENCES}

1) Abou-Elhamd KE, Al-Sultan AI, Rashad UM. Simulation in ENT medical education. J Laryngol Otol 2010;124(3):237-41.

2) Deutsch ES. Simulation in otolaryngology: smart dummies and more. Otolaryngol Head Neck Surg 2011;145(6):899-903.

3) Rudman DT, Stredney D, Sessanna D, Yagel R, Crawfis R, Heskamp $\mathrm{D}$, et al. Functional endoscopic sinus surgery training simulator. Laryngoscope 1998;108(11 Pt 1):1643-7.

4) Ledingham AD, English JD, Akyalcin S, Cozad BE, Ontiveros JC, Kasper FK. Accuracy and mechanical properties of orthodontic models printed 3-dimensionally from calcium sulfate before and after various postprinting treatments. Am J Orthod Dentofacial Orthop 2016;150(6):1056-62.

5) Zopf DA, Mitsak AG, Flanagan CL, Wheeler M, Green GE, Hollister SJ. Computer aided-designed, 3-dimensionally printed porous tissue bioscaffolds for craniofacial soft tissue reconstruction. Otolaryngol Head Neck Surg 2015;152(1):57-62.

6) Kumta S, Kumta M, Jain L, Purohit S, Ummul R. A novel 3D template for mandible and maxilla reconstruction: rapid prototyping using stereolithography. Indian J Plast Surg 2015;48(3):263-73.

7) Chiesa Estomba CM, González Fernández I, Iglesias Otero MÁ. How we do it: anterior and posterior nosebleed trainer, the 3D printing epistaxis project. Clin Otolaryngol $2016 \mathrm{Jul} 25$ [Epub ahead of print]. https://doi.org/10.1111/coa.12711.

8) Shiraishi I, Yamagishi M, Hamaoka K, Fukuzawa M, Yagihara T. Simulative operation on congenital heart disease using rubber-like urethane stereolithographic biomodels based on 3D datasets of multislice computed tomography. Eur J Cardiothorac Surg 2010;37(2):302-6.

9) Brown BN, Siebenlist NJ, Cheetham J, Ducharme NG, Rawlinson JJ, Bonassar LJ. Computed tomography-guided tissue engineering of upper airway cartilage. Tissue Eng Part C Methods 2014;20(6): 506-13.

10) Yoo YS. Custom-made T-tube designed by 3 -D reconstruction technique, a preliminary study. Korean J bronchoesophagol 2010;16(2):131-7.

11) Bauermeister AJ, Zuriarrain A, Newman MI. Three-dimensional printing in plastic and reconstructive surgery: a systematic review. Ann Plast Surg 2016;77(5):569-76.

12) Chia HN, Wu BM. Recent advances in $3 \mathrm{D}$ printing of biomaterials. J Biol Eng 2015;9:4.

13) Goldstein TA, Smith BD, Zeltsman D, Grande D, Smith LP. Introducing a 3-dimensionally printed, tissue-engineered graft for airway reconstruction: a pilot study. Otolaryngol Head Neck Surg 2015; 153(6):1001-6.

14) Konopnicki S, Sharaf B, Resnick C, Patenaude A, Pogal-Sussman $\mathrm{T}$, Hwang KG, et al. Tissue-engineered bone with 3-dimensionally printed $\beta$-tricalcium phosphate and polycaprolactone scaffolds and early implantation: an in vivo pilot study in a porcine mandible model. J Oral Maxillofac Surg 2015;73(5):1016.e1-11.

15) Salmi M. Possibilities of preoperative medical models made by $3 D$ printing or additive manufacturing. J Med Eng 2016;2016:6191526.

16) Tam MD, Laycock SD, Jayne D, Babar J, Noble B. 3-D printouts of the tracheobronchial tree generated from CT images as an aid to management in a case of tracheobronchial chondromalacia caused by relapsing polychondritis. J Radiol Case Rep 2013;7(8):34-43.

17) Chang JM, Yoo YS, Kim DW. Application of three-dimensional reconstruction in esophageal foreign bodies. Korean J Thorac Cardiovasc Surg 2011;44(5):368-72.

18) Izquierdo L, Leiva L. Virtual angioscopy assessment for acute type $\mathrm{B}$ aortic dissection endovascular repair. Catheter Cardiovasc Interv 2010;75(1):32-4.

19) Mazzeo S, Caramella D, Gennai A, Giusti P, Neri E, Melai L, et al. Multidetector CT and virtual endoscopy in the evaluation of the esophagus. Abdom Imaging 2004;29(1):2-8.

20) Nakasato T, Sasaki M, Ehara S, Tamakawa Y, Muranaka K, Yamamoto $\mathrm{T}$, et al. Virtual CT endoscopy of ossicles in the middle ear. Clin Imaging 2001;25(3):171-7.

21) Heo G, Yoo YS, Kim SW. Virtual endoscopy of impacted foreign bodies in tracheal and esophageal model. Korean J OtorhinolaryngolHead Neck Surg 2011;54(5):339-43.

22) Mowry SE, Jammal H, Myer C 4th, Solares CA, Weinberger P. A novel temporal bone simulation model using $3 \mathrm{D}$ printing techniques. Otol Neurotol 2015;36(9):1562-5.

23) Inabnet $W B$, Gagner $M$. Endoscopic thyroidectomy. J Otolaryngol 2001;30(1):41-2.

24) Koh YW, Kim JW, Lee SW, Choi EC. Endoscopic thyroidectomy via a unilateral axillo-breast approach without gas insufflation for unilateral benign thyroid lesions. Surg Endosc 2009;23(9):2053-60.

25) Liang F, Fan S, Han P, Cai Q, Lin P, Chen R, et al. Endoscopic-assisted selective neck dissection via small lateral neck incision for earlystage (T1-2N0M0) head and neck squamous cell carcinoma: 3-year follow-up results. Surg Endosc 2017;31(2):894-900. 